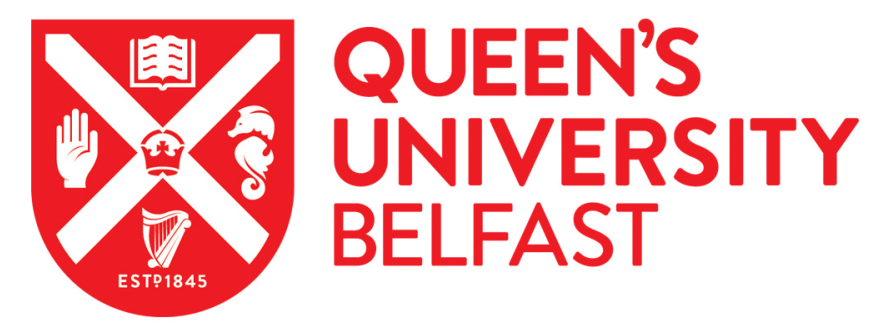

\title{
University Knowledge Transfer: Exploring organisational structures to create strategic alignment
}

Alexander, A., \& Miller, K. (2016). University Knowledge Transfer: Exploring organisational structures to create strategic alignment. In The Proceedings of The 2016 ISPIM Forum Boston, USA 13-16 March 2016 ISPIM. http://ispim.org/publications/past-proceedings/

\section{Published in:}

The Proceedings of The 2016 ISPIM Forum Boston, USA 13-16 March 2016

\section{Document Version:}

Peer reviewed version

Queen's University Belfast - Research Portal:

Link to publication record in Queen's University Belfast Research Portal

\section{Publisher rights}

Copyright 2016 the authors.

This work is made available online in accordance with the publisher's policies. Please refer to any applicable terms of use of the publisher.

\section{General rights}

Copyright for the publications made accessible via the Queen's University Belfast Research Portal is retained by the author(s) and / or other copyright owners and it is a condition of accessing these publications that users recognise and abide by the legal requirements associated with these rights.

Take down policy

The Research Portal is Queen's institutional repository that provides access to Queen's research output. Every effort has been made to ensure that content in the Research Portal does not infringe any person's rights, or applicable UK laws. If you discover content in the Research Portal that you believe breaches copyright or violates any law, please contact openaccess@qub.ac.uk. 


\title{
University knowledge transfer: Exploring organisational structures to create strategic alignment
}

\author{
Allen T. Alexander* \\ Centre for Innovation \& Service Research, University of Exeter \\ Business School, Streatham Court, Exeter, EX4 4ST \\ United Kingdom. \\ E-mail: a.t.alexander@exeter.ac.uk
}

\section{Kristel Miller}

Queen’s Management School, Queen’s University, Riddel Hall, 185 Stranmillis Road, Belfast, BT95EE, United Kingdom.

E-mail: kristel.miller@qub.ac.uk

* Corresponding author

\begin{abstract}
Whilst knowledge and technology transfer unarguably present an important source of wealth for a nation and an important component of a modern University's offering to society, the management of this activity is complex and as a result many economies struggle to realise their expectations.

According to extensive, policy-driven surveys academics and commercial organisations are quick to blame inflexible and bureaucratic university transfer offices and administrators for this shortfall. However this research identifies interdependent and complex management practices coupled with equally complex organisational architectures which lead to issues of conflicting pressures and ambiguous governance. The research also goes on to illustrate a number of 'structural' solutions that universities have adopted to try to side-step some of the problems.

The findings presented within this paper result from a snap shot survey, undertaken as part of a wider more in-depth study, spanning a 10 year period and focussing on universities and public research organisation's knowledge and technology transfer capability in Europe and from other key areas around the world. The purpose of the paper is to begin allow senior managers in research-centred organisations to visualise their respective organisational structures and to reference them against their governance, service offering and management competences.
\end{abstract}

Keywords: Knowledge transfer, University, Industry, Subsidiary, Strategy, Operational Alignment. 


\section{Introduction}

The importance of university-industry knowledge transfer activities within regions is not a new phenomenon. Within Europe, since the $19^{\text {th }}$ century, universities have been considered to play an anchoring role in society with the core aim of accelerating growth and social prosperity (Smallbone et al., 2015). In recent years there has been renewed emphasis on the benefit that knowledge transfer activities between university-industry can have, particularly as a driver of innovation and economic growth (Guerrero et al., 2015).

University-industry knowledge transfer encapsulates a wide range of activities ranging from more formal and transactional activities such as spin out firms, patents, joint ventures, contract research, to more collaborative and relational engagement activities such as collaborative research, shared research facilities, secondments, training and continued professional development, student placements and student projects. A detailed list of the potential transfer channels can be seen in table 1 .

There are many challenges in university-industry knowledge transfer identified within current literature, viewed from a university and an industry perspective. From a university perspective, knowledge transfer activities do not always fit within the norms of traditional universities where strategic emphasis is often on publications, funding, teaching and specific technology commercialisation activities. Often academics are not contractually obliged to engage in knowledge transfer activities and performance mechanisms in universities often do not motivate academics to commit time and resources to these types of activities when success metrics are often aligned to excellence in research and teaching (O’Shea et al., 2008).

Furthermore, from both an academic and industry perspective, it is widely noted that the perceived bureaucracy and inflexibility of university processes and their administrators (PACEC, 2012) limits university-industry knowledge transfer. Whilst it is to be expected that universities will have a certain levels of bureaucracy regarding knowledge transfer actvities due to many of these activies often being publically funded, prior research (Miller et al., 2014) suggests that challenges dervived from the internal organisational tensions that exist between the different institutional demands placed on knowledge transfer offices, faculty departments and on individual academics which often conflict with the goals of external stakeholders. Knowledge transfer offices (KTO) are meant to act as a mediator bridging these relationships (Perkmann and Schildt, 2015), however, conflicting priorities of stakeholders can cause strategic challenges relating to decision making about what knowledge transfer activities they should offer and prioritise and how to allocate scarce resources. Knowledge transfer offices are also required to devise their own performance mechanisms but they often lack resources, legitimacy and power when faced with trying to manage this complexity engendered by the multiple and sometimes contradictory expectations of university environments coupled with external stakeholder expectations (Miller et al. 2014). This signals the importance of understanding the different structural architecture of KTOs and how this can impact upon knowledge transfer activities. This leads to our aim which is to explore the structural arrangements of knowledge transfer offices to identify if different structures help overcome different strategic and operational challenges involved in university-industry knowledge transfer. 


\begin{tabular}{|c|c|}
\hline $\begin{array}{c}\text { Knowledge } \\
\text { Transfer Channel }\end{array}$ & Channel Definition \\
\hline Shared Facilities & $\begin{array}{l}\text { This is where a University and a Commercial partner join together to invest in the } \\
\text { development and operation of a facility or piece of equipment that will yield benefit } \\
\text { to both parties. }\end{array}$ \\
\hline Patent or License & $\begin{array}{l}\text { This is where a particular piece of knowledge or know-how is developed and then } \\
\text { protected by either an academic partner or a commercial partner. The knowledge } \\
\text { transfer is achieved by granting a license for the other party to use this knowledge or } \\
\text { technique in their activities. }\end{array}$ \\
\hline Joint Conference & $\begin{array}{l}\text { Where the audience consists of company employees and academic colleagues and } \\
\text { speakers are taken from both groups. The speakers present materials and propose } \\
\text { theories to attendees. }\end{array}$ \\
\hline Spin-out & $\begin{array}{l}\text { Where University personnel join together with commercial partners to create a } \\
\text { formally recognised company (as a new legal entity). }\end{array}$ \\
\hline $\begin{array}{l}\text { Writing } \\
\text { Professional } \\
\text { Journal } \\
\text { Publication }\end{array}$ & $\begin{array}{l}\text { This is where academic and professional people develop a paper together that } \\
\text { defines particular research or knowledge that they possess. These papers are then } \\
\text { collated into professional journals and these are then read by scholars and business } \\
\text { folk alike. }\end{array}$ \\
\hline Networks & $\begin{array}{l}\text { Groups of professionals and/or academics that come together and meet face-to-face } \\
\text { under a banner of common interest or subject discipline. They may meet both } \\
\text { formally and informally (socially) and discuss aspects of their shared interest and } \\
\text { debate research or knowledge and its value and applicability to their own work } \\
\text { environments. }\end{array}$ \\
\hline Training \& CPD & $\begin{array}{l}\text { This is where commercial partners are encouraged to keep their professional } \\
\text { knowledge up to date with new developments and techniques. Often delivered by } \\
\text { academics, activity occurs in a similar way as teaching, where the teacher or tutor } \\
\text { codifies their knowledge in order to transfer this knowledge in a lecture or tutorial } \\
\text { based study activity. }\end{array}$ \\
\hline $\begin{array}{l}\text { Contract Research } \\
\text { \& Consultancy }\end{array}$ & $\begin{array}{l}\text { This is where a company has a problem and wishes for either: } \\
\text { - A "known" solution to be applied to their problem (Consultancy); } \\
\text { - An unknown solution is researched and proven and then presented to the } \\
\text { company in order for it to be applied to the company problem. }\end{array}$ \\
\hline $\begin{array}{c}\text { Student } \\
\text { Placements / } \\
\text { Graduate } \\
\text { Employment }\end{array}$ & $\begin{array}{l}\text { Involves the transfer of a recent graduate into a business or company partner, where } \\
\text { they are employed on either a placement or permanent basis. }\end{array}$ \\
\hline Joint Supervision & $\begin{array}{l}\text { This is where academics and industrialists come together to jointly supervise a piece } \\
\text { of research or academic study (Joint Master Thesis, PhD or Industrial CASE). }\end{array}$ \\
\hline Secondment & $\begin{array}{l}\text { This is where a member of staff is present for a period of time in another } \\
\text { organisation with a focus on exchanging or contextualising knowledge between } \\
\text { partners. }\end{array}$ \\
\hline $\begin{array}{l}\text { Collaborative } \\
\text { Research }\end{array}$ & $\begin{array}{l}\text { This is where a problem or gap in knowledge exists and commercial and academic } \\
\text { partners agree to work together to discover new knowledge surrounding the problem } \\
\text { or to propose solutions that may solve the problem. }\end{array}$ \\
\hline Joint Venture & $\begin{array}{l}\text { This is where a company partner and an academic partner come together to } \\
\text { investigate or promote a solution to a problem. It differs from a spin-out in as much } \\
\text { as there is not a new legal entity, in the form of a company, but it does rely on a set } \\
\text { of legal agreements being created that ties the parties together with a common } \\
\text { purpose. }\end{array}$ \\
\hline
\end{tabular}

Table 1 - Framework of the Channels of Knowledge Transfer (Alexander and Childe, 2012a)

\subsection{Complexities of knowledge transfer between diverse stakeholders}

Prior research has identified numerous success indicators and barriers to universityindustry knowledge transfer (Agrawal, 2001; Miller et al., 2016); however, many of these studies adopt a macro and policy level of abstraction (Bruneel, 2013; Carayannis and 
Campbell, 2011; Bozeman et al, 2013). One common reoccurring theme reported in the literature which underpins the success of knowledge transfer, from both commercial organisations and academic institutions, relates to the perceived bureaucracy and inflexibility of university processes and their administrators (PACEC, 2009, PACEC, 2012). Whilst it not surprising that organisations as large and as multifarious as universities will have management systems and organisational processes that are complex, this is potentially aplified by their historical reliance on public funding. A number of studies, at a 'macro-level' (Lee, 1998; Pache and Santos 2010; McAdam et al., 2012; Bozeman 2013, Miller et al., 2014) identify that a major contributor in the problem of percieved bureaucracy and inflexibility results from the plethora of internal and external stakeholders, each with an interest in the growth of knowledge transfer, but in turn with a range of expectation or more granularly a set of rules and regulations that must be adhered to.

Organisational strategies dictate that knowledge transfer offices should act as a mediator, bridging relationships with both internal university and external regional and national stakeholders (Howells 2006; Perkmann and Schildt. 2015); however, they too are faced with their own performance mechanisms and often lack resources and power when faced with trying to manage the complexity engendered by the multiple and sometimes contradictory expectations of university remits and different departmental processes which is all complicated further by external stakeholder expectations (Miller et al., 2014). The extent of the challenges faced can be considered to be linked to the structural architecture of KTOs where KTOs embedded within universities are often considered to be intertwined within more institutional bureaucracy and often objectives are not fully aligned to those of external stakeholder in comparison to those those which are outsourced. Research in this area is needed to more fully understand the different structural arrangements of KTOs to try to identify particular model's where multiple internal and external stakeholders goals can be simultaneously achieved (Bozeman et al, 2013), to improve the efficiency and effectiveness of university-industry knowledge transfer operations.

\subsection{Adopting a Practical Perspective}

Whilst issues of inflexibility, bureaucracy, the time available or the motivation of academics are no doubt important factors affecting the process of knowledge transfer (Siegel et al., 2003; Agrawal, 2001; Prigge , 2005) we suggest there are also more practical problems that may highlight additional pressures on knowledge transfer offices.

Firstly, knowledge itself is complex. It is, by its very nature, difficult to comprehend, viewed by many as intrinsically embedded in the "knower" and that cannot be "commoditised" or "traded" as part of a transaction between two parties. This is often ignored when developing university knowledge transfer strategies or considering the structural arrangements of KTOs. Any growth or management strategy, both at a policy and an institutional level, must recognise and pay attention to this complexity. One practical example of this is where there is an organisational desire to raise income from patent and license sales, but where only $30 \%$ of the faculty within the organisation are researching in scientific disciplines and the KTO employees very generalist staff. Patenting strategies are typically fraught with practical difficulties in social science disciplines and softer, less formal activities might be more appropriate (Alexander and Childe, 2011).

Secondly, as mentioned, knowledge transfer involves multiple internal stakeholders, within which there are often multiple actors (for example a university might mobilise their IP 
management specialists, their insurers, their contracts team etc. a company its lawyers, accountants or consultants etc.) which in turn span various organisational boundaries. These multiple actors and stakeholders create further complexity in the process of knowledge transfer and this has been recognised in studies focused across a multi-level and/or multi-stakeholders perspective (Perkmann et al., 2013; Bozeman et al., 2013).

Thirdly, the speed of action required by the commercial stakeholders can often place a university knowledge transfer team under considerable pressure (Sharifi and Liu, 2010) depending on the KTO architecture and structural arrangements, since their own intrinsic tempo may be regulated by other institutional departments (as suggested above - their legal, IP management, legal, contracting team etc, for example).

Finally one important aspect of knowledge transfer that must not be overlooked is the requirement for reciprocity. Knowledge does not merely 'flow' from a university to a company, there is a feedback or reciprocal loop that means that important aspects of diffusion and adoption can be understood by the knowledge creators to inform their iterations of the outputs to ensure future outcomes are realised by the end-users (Alexander and Childe, 2012b). Within literature it is reported that industry often see universities as being 'ivory towers' with issues of differences in language reported signalling the important of an effective KTO to bridge boundaries between academics and industry (Mowery et al., 2015).

Therefore, to manage the transfer of knowledge from university to industry, managers and decision makers must be aware of the various definitions and attributes of knowledge; be able to respond to this multi-level, multi-actor complexity by mobilising complex cognitive processes (Halford et al., 1998) and undertake all this in a timely manner. It is therefore no surprise that managing knowledge transfer processes can lead to an 'information overload', which often results in 'decision paralysis' (Eppler and Mengis, 2004). The resulting confusion results in KTO managers struggling for decisive clarity, unable to find solutions within a reasonable time or worse, passively choosing to delay, often beyond the point where action was required. We suggest that this is the root cause of the perception of bureaucracy and inflexibility reported by both academics and companies, when citing factors leading to a lack of engagement. We also suggest that the extent of these issues identified will be reliant upon the architecture of the KTO. This leads us to our research question:

What are the organisational architectures prevalent across knowledge transfer offices and to what extent do different architectures help solve the problems of institutional bureaucracy and complex multi-level and multi actor problems

\subsection{Methodology}

This research aims to theorise and build theory (Yin, 2011). It utilises data gained during a snap-shot survey of 12 international knowledge transfer organisations in 2013 and data collected during a longitudinal survey of two particular knowledge transfer offices between 2007 and 2010.

Table 2 shows a categorisation of the respondent organisations in the 2013 snap shot survey. The survey was aimed at unravelling the different schemes knowledge transfer offices were offering to support their institution's open innovation goals. The preliminary 
findings from this study were reported in Alexander et al (2012). The two knowledge transfer organisations which then participated in the longitudinal survey between 2007 and 2010 are UK4 and FR1.

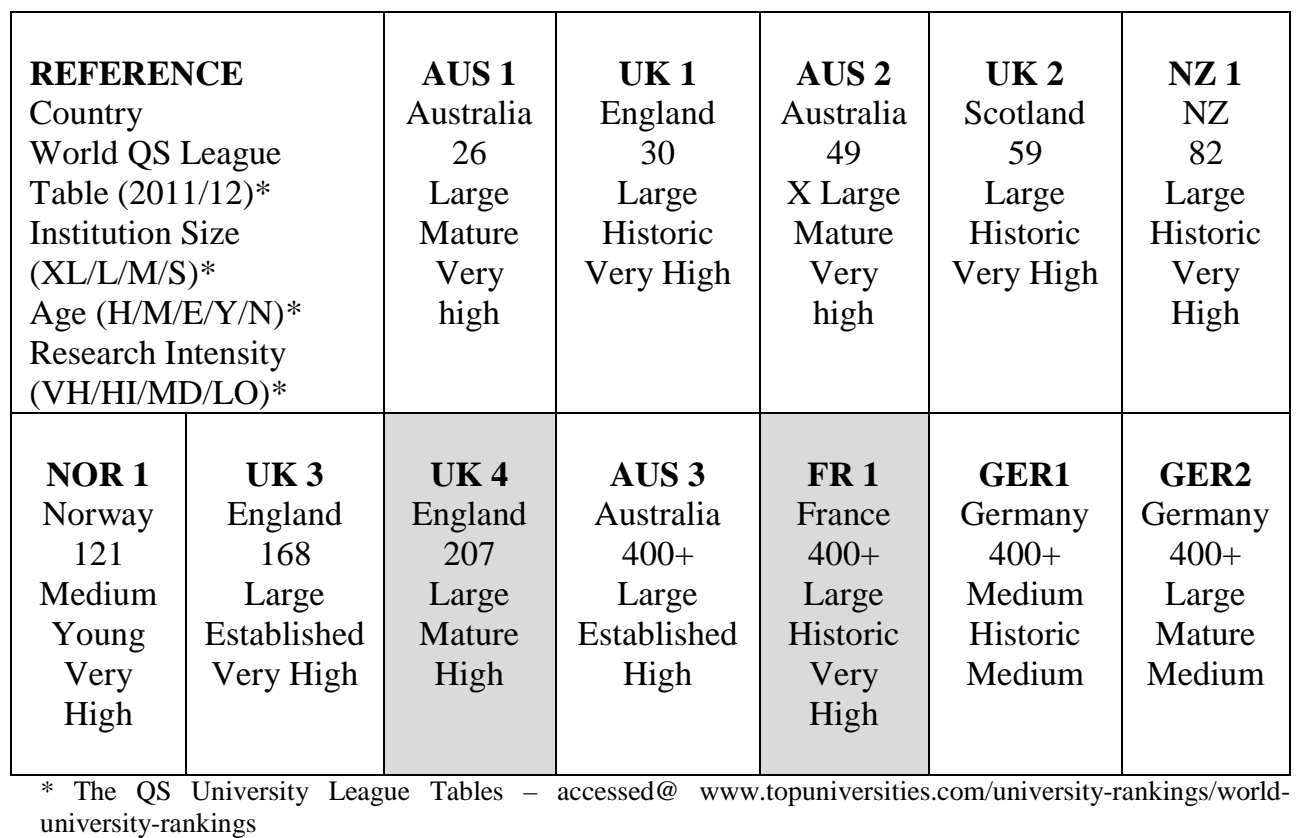

Table 2 - The comparators institutions

In order to answer the research question, first, we will consider the relative structural architectures of knowledge transfer organisations and examine how they fit within their host universities and compare this to the services they are offering. We will then discuss the theoretical and practical challenges involved in managing a portfolio of university knowledge transfer activities and compare these to the respective architectures of the knowledge transfer offices. Finally we will consider the potential benefit that these architectures offer their host institutions whist also considering if they create barriers or problems themselves.

\subsection{Research Findings}

The survey findings identify a number of organisational architectures that have been used to structure and to manage the activity of knowledge transfer. These include universities who manage their respective knowledge transfer activity within faculty-based, disciplinespecific offices; or universities that centralise this activity, creating institutional knowledge transfer offices which serve all, or the majority of the faculties accordingly. Another group of universities choose to provide a 'special purpose vehicle' or subsidiary company operating at 'arms-length' and acting as a conduit for knowledge and intellectual property. Furthermore, other universities choose to create virtual entities, where the sharing of resources and intellectual property happens across a number of universities. Finally there is a group of universities that choose to 'contract-out' their knowledge transfer and applied 
research to entirely separate legal entities, operating under complex framework agreements to enable royalty and income redistribution.

As well as identifying the relative structures of these knowledge transfer organisations and their relationship with their overarching institutions we also identified, to some extent, the range of services that these organisations offered in terms of which channels they favoured and in more detail how their respective strategies could relate to their overarching governance.

\subsection{Knowledge transfer offices located within their institutions}

Of the knowledge transfer offices reviewed, four had adopted the models shown in figure 2. They had not chosen to separate their respective knowledge transfer office from their main institution. Staff employed in the knowledge transfer office were the institution's own staff and their overarching management and leadership was provided by the senior administrative manager (e.g. the Registrar, Chief Operating Officer etc.). Of the four adopting this model, only one had faculty-based knowledge transfer offices, offering all the channels of knowledge transfer shown in table 1 , whilst the others offered the full range of knowledge transfer channels using a centralised administrative service for knowledge transfer.

\subsection{Knowledge transfer offices located within arms-length institutions}

Of the knowledge transfer offices reviewed four had adopted the models shown in figure 3. Each institution had established a special purpose legal entity, which was a whollyowned subsidiary of the university. They each had given this entity differing degrees of operational remit and autonomy as part of their memorandums and articles. The subsidiaries were controlled by a board of directors, often consisting of a number of senior administrative officers from the parent institution. In addition some had membership from senior institutional academics, others with membership drawn from the regional industrial community. In terms of staff employment, there was a mix of secondees from the parent institution or directly employed staff, likewise there was a mix of parent-services utilised in each (for example - one had its own legal officer, whilst others used the parents legal office, one had its own accountant whilst others used their parent accounting facilities etc.). Each subsidiary offered a different range of knowledge channels - with the three UK-based subsidiaries offering Consultancy (and for one Contract Research) and the Australian university offering a more complex range of patents and licenses, contract research, consultancy, shared facilities and spin-outs. In terms of ownership of Intellectual Property, each subsidiary acted on behalf of the patent and therefore did not own any IP that they traded or shared. 


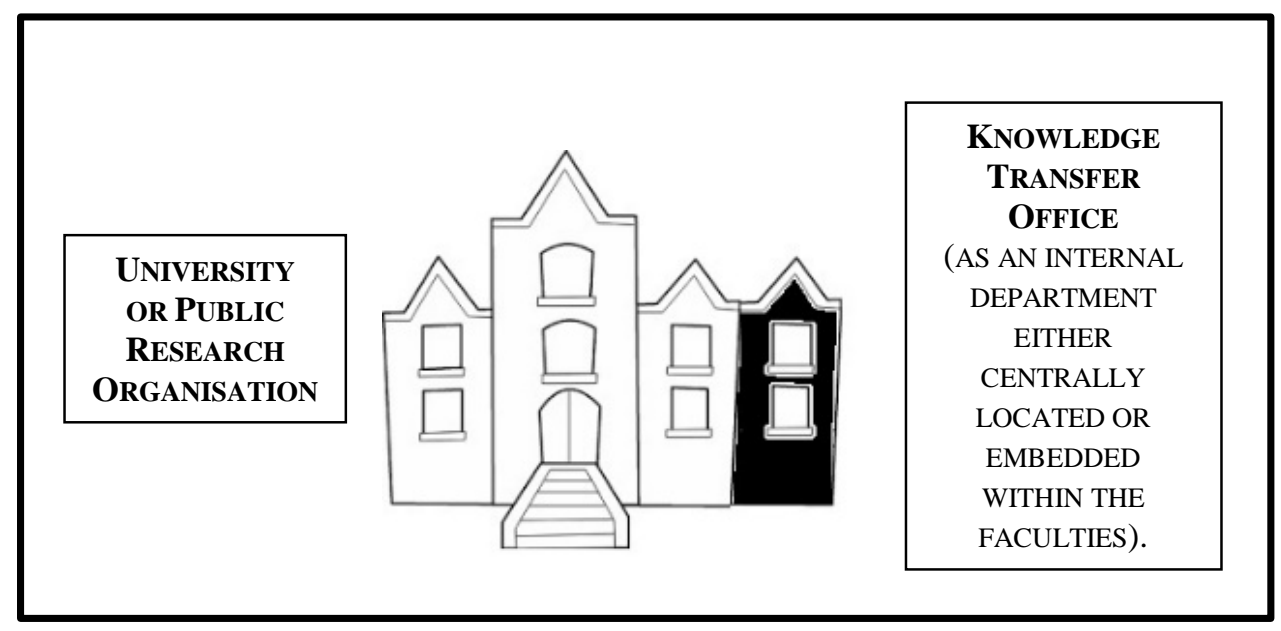

Figure 2 University with an internal department as a Knowledge Transfer Office.

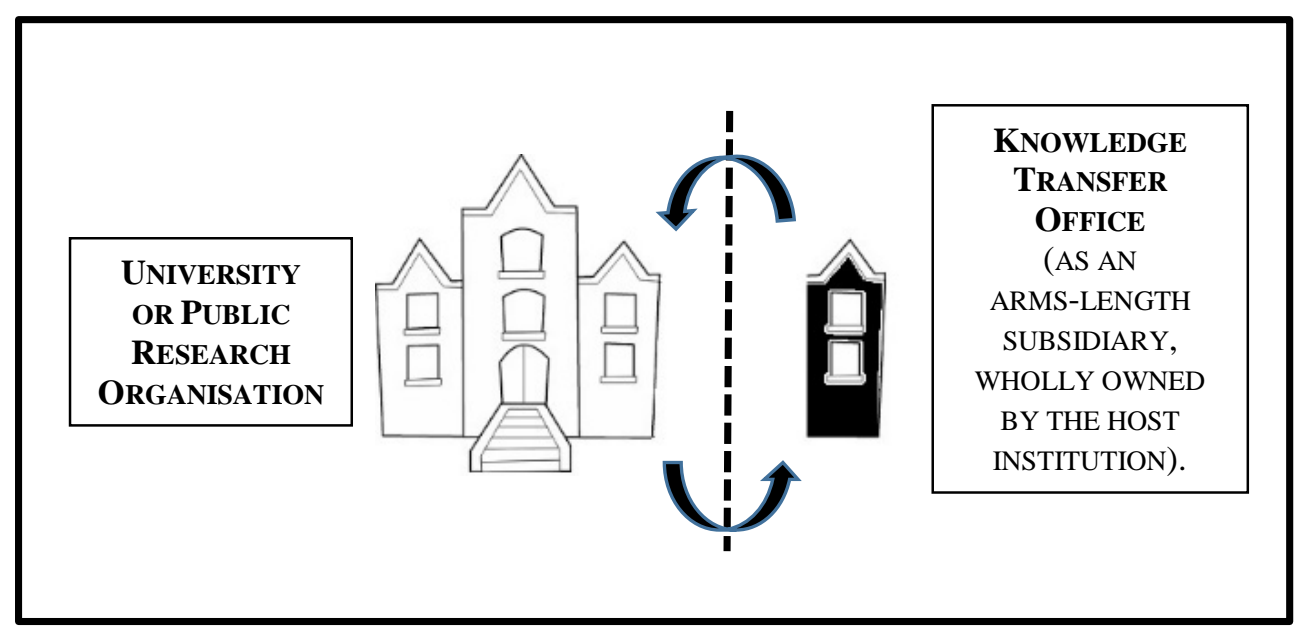

Figure 3 University with an arms-length subsidiary as a Knowledge Transfer Office.

\subsection{Knowledge transfer offices based outside of their institutions}

Two knowledge transfer organisations stood out as different, both from Germany (Ger 1 and Ger 2). These knowledge transfer organisations where legal entities in their own right and were only linked to institutions through regional economic policy and thus, had memorandums and articles linking them, by agreement, to their local host university. Staff employed in the knowledge transfer organisations were directly employed, and the knowledge transfer organisations employed senior academic staff from the host universities directly through proportional contracts. In terms of intellectual property ownership, much of the university intellectual property was licensed for resale to the 
knowledge transfer office, but significant amounts of IP were created directly by the knowledge transfer organisations themselves - either through development of institutional IP under license or by undertaking contract research and consultancy on behalf of the host organisation. Contracts also existed to locate Post Graduate Research students and programmes of Industrial Doctorates directly under the supervision of the knowledge transfer organisation. In terms of channels of knowledge transfer, the majority of the channels as shown in table 1 were offered directly by the knowledge transfer office and in terms of knowledge creation, significant amounts of knowledge were created within its operational activities.

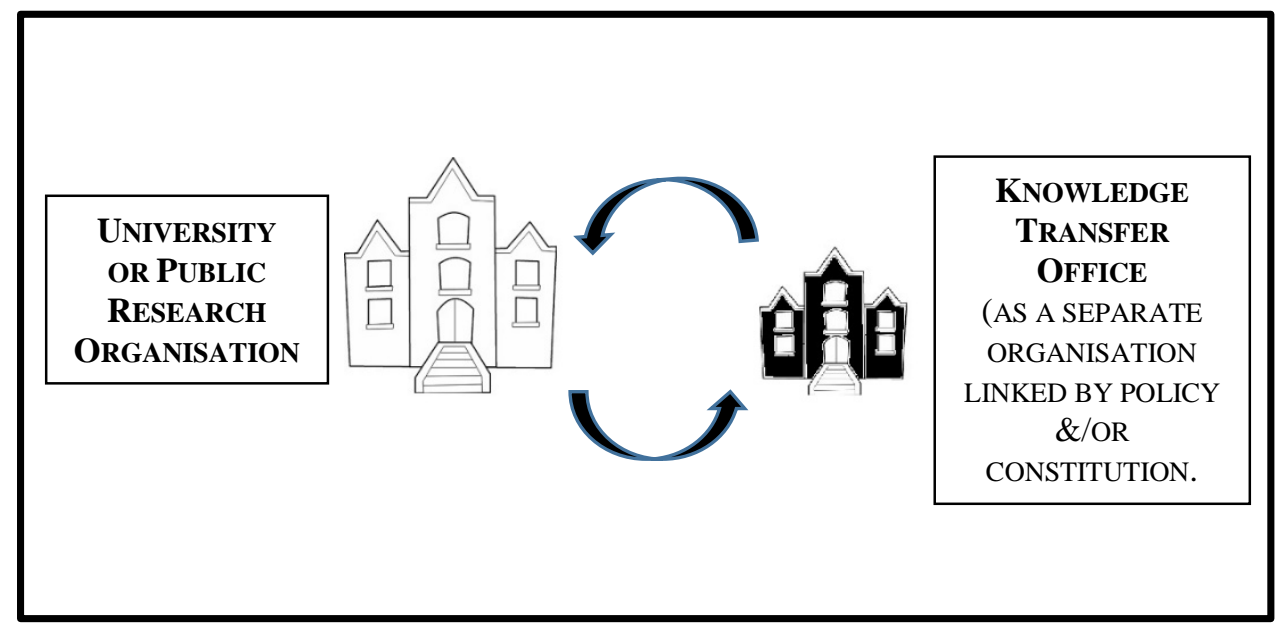

Figure 4 University with a separate Knowledge Transfer Office.

\subsection{Knowledge transfer offices operating on a virtual platform.}

One particular example arising from FR1 also offered a different perspective to models explained previously. Figure 4 represents a regional knowledge transfer approach. Each institution in a geographic region signed up to an agreement to create joint-ventures that in turn receive financial support and seconded staff from each institution to create a vehicle for knowledge transfer. Each virtual organisation has a specialist sectoral focus - for example agriculture, marine, high-technology, automobile and these organisation mirror the regional focus for science parks, incubation facilities and business support. Intellectual Property is retained by the originator and knowledge creation is not undertaken within the organisations themselves. In terms of channels offered, this virtual organisation only offered the more formal and established channels of knowledge transfer. 


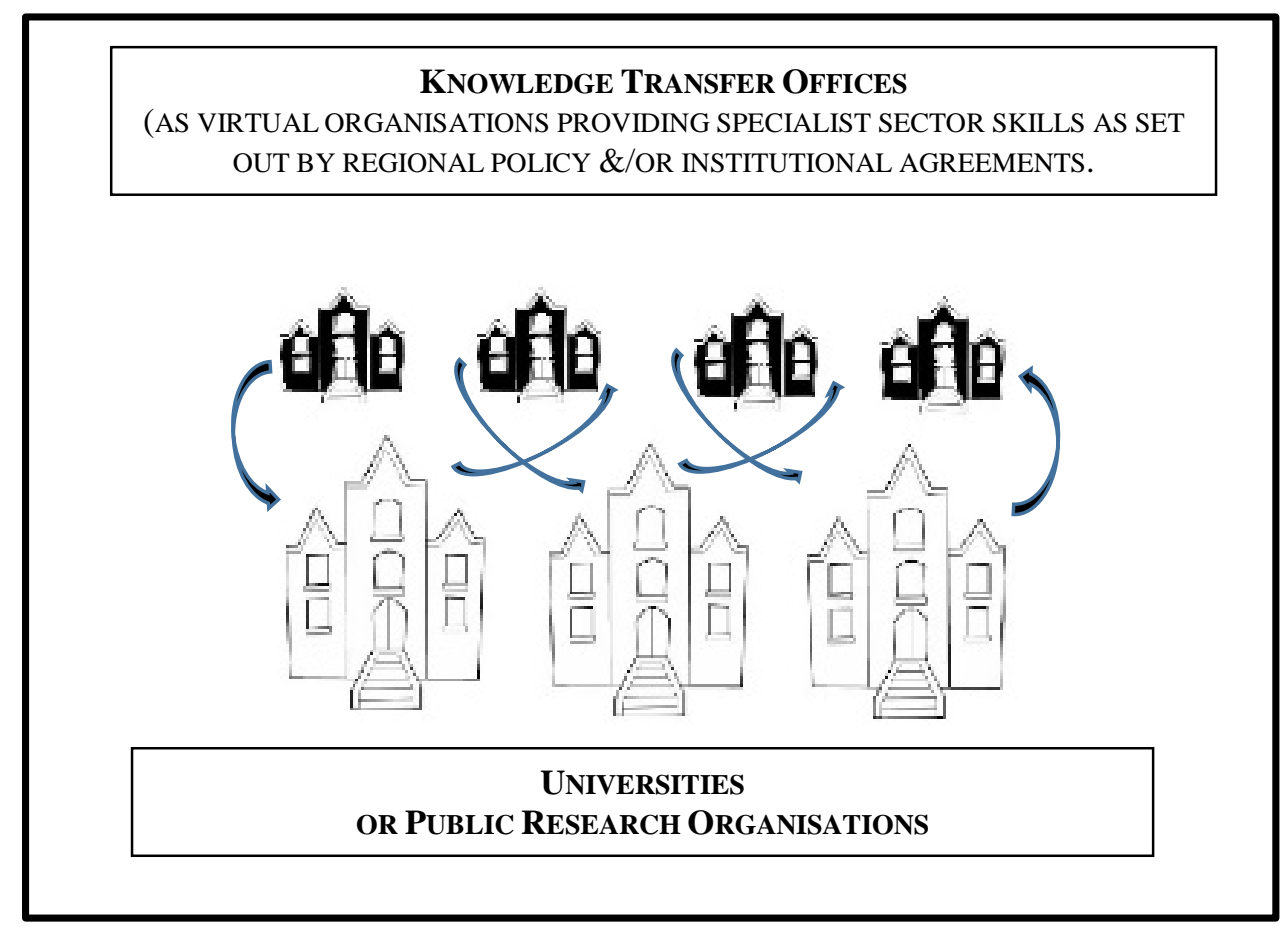

Figure 5 Regional universities creating virtual discipline-specific Knowledge Transfer Offices.

\subsection{Discussion}

What is evident from the preliminary research undertaken within this study is that host institutions have adopted different structures relative to their respective knowledge transfer offerings. Of these structures, whilst we cannot ascertain from the data the primary motivations for establishing these architectures, some offer particular benefits and can overcome some of the problems identified earlier in this paper.

In terms of the criticisms of bureaucracy and institutional process inefficiency, it would seem reasonable to assume that by creating an autonomous (separate KTO) or semiautonomous (arms-length KTO) organisations there could be a number of benefits. First it may allow better alignment of internal university procedures and resourcing levels with the tempo of commercial requests. Often this is inherently difficult to do when a KTO is embedded within an institution where the KTO may not be able to react quick enough to external stakeholders due to institutional bureaucracy, whereas a separate or semiautonomous KTO may reduce some of this. These type of structure employ specialist staff to address IP and legal aspects of the knowledge transfer, therefore this increases the efficiency of processes and processes are within the control of the KTO giving them control over the timeliness of knowledge transfer activities (thus helping address the need to align the tempo to commercial requests). By the very nature of the KTOs being small this will bring with it an inherent level of agility that the institution itself will struggle to achieve. 
In turn this effectively reduces the number of internal stakeholders involved in the activity of knowledge transfer, with the KTO answering to its board of directors (and in the case of arm's-length to its shareholder/parent), rather than across a range of professional services or faculty senior managers for example. To some extent, the separate KTO can also establish its own performance mechanisms and can select some performance mechanisms that would typically not reflect the host institution (for example timeliness to respond to enquiries, duration of negotiations, lead time to sale for patents etc.) as well as the harder income driven metrics which will likely be imposed on the KTOs embedded within university institutions. These additional metrics are important to build up trust and repoire with commercial organisations.

However autonomous or separate KTO are also likely to have inherent problems too. The first is the relationship with the parent in terms of start-up funding. Totally independent KTO are unlikely to be able to raise start-up capital from investors and so will likely require either policy-driven public funding or a loan or other form of senior lending from their institutions. In the case of the German examples (Ger1 and Ger2), these Fraunhofer Institutes are reported to gain income from public funding and latterly from holding their own royalties and income streams accordingly. These organisations have grown considerably under this mechanism and some of the larger Fraunhofer Institutes are now on a par with major universities in terms of revenues and size. In terms of arms-length organisations then it is normal for there to be some form of start-up loan and then for the organisation to trade, placing its operating profits back into the host institution to repay its start-up capital and to service is host organisation agreements on an ongoing basis. The second major problem with arms-length and separate KTOs is the ability to attract and to retain academic talent. Whilst in the Fraunhofer Institutes this is achieved by appointing senior academic staff on a proportional contract, there is a tendency in the arms-length organisations for a barrier to be perceived between the academic teams and the subsidiary. This is particularly likely to impact the establishing and maintaining of knowledge reciprocity.

In terms of the internal KTOs, their proximity to the academics should be an advantage in terms of maintaining the two directions flows of knowledge, as the KTOs are a bridge and not a legal entity. It could be argued that a faculty setting for the internal knowledge transfer offices may increase this knowledge reciprocity further.

Once key potential benefit for the faculty-based and the virtual knowledge transfer offices is the ability to recruit and align staff with the respective specialities of either the region (in terms of the virtual KTO) or the faculty (for the internal faculty-based KTO). In the virtual KTO specialist staff from the respective institutions are seconded to the virtual KTO, each residing within their own speciality. To some extent these two structures also go some way to address the problems with more generalist KTO staff being involved in different types of knowledge - for example scientific knowledge vs. social science knowledge. Virtual KTOs can establish themselves to focus on social science activity and can second staff from the host institutions across a region and focus on appropriate mechanisms for knowledge transfer, whilst other groups within the virtual KTO can focus on physical science and utilise the most appropriate mechanisms accordingly.

The final most notable difference evident from the data collected is the range of knowledge transfer channels being adopted by the organisations and how these alter based on their 
relative structural architectures. Some of these structural solutions offer different channels of knowledge transfer and a comparison is presented in table 3.

It is evident that there is a distinct bias in the virtual organisations studied toward the more codified and more formalised channels of knowledge transfer. Patent and Licenses, Spinout and joint ventures are predominantly the channels offered in this structural model. In general terms the opposite structural configuration of internal KTOs bring forward a wider and more complete selection of knowledge transfer channels. The other notable reflection is that the UK arms-length subsidiaries appear to only handle similar channels as the virtual KTOs, with the addition of consultancy and contract research.

The Fraunhofer model identified in the separate KTO architecture does not follow this pattern and these organisations offer a wide range of knowledge transfer channels. This could be in part, because they have a knowledge creation role as well as a knowledge transfer role.

\begin{tabular}{|c|c|c|c|c|c|c|c|c|c|c|c|c|c|}
\hline & & \multicolumn{12}{|c|}{$\begin{array}{l}\text { Knowledge Transfer Channels ordered according to degree of knowledge } \\
\text { codification, as established by Alexander \& Childe, } 2013\end{array}$} \\
\hline & & 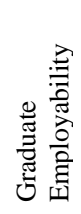 & 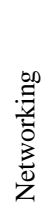 & 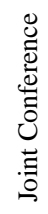 & 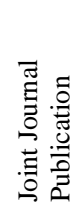 & 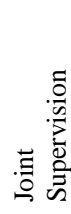 & 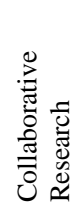 & 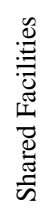 & 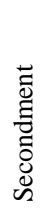 & 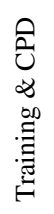 & 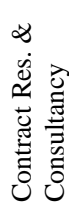 & 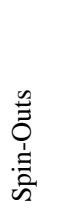 & 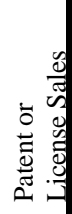 \\
\hline \multirow{4}{*}{ Fig. 1} & UK2 & $\mathrm{Y}$ & $\mathrm{Y}$ & $\mathrm{Y}$ & $\mathrm{Y}$ & $\mathrm{Y}$ & $\mathrm{Y}$ & $\mathrm{Y}$ & $\mathrm{Y}$ & $\mathrm{Y}$ & $\mathrm{Y}$ & $\mathrm{Y}$ & $\mathrm{Y}$ \\
\hline & NZ1 & $\mathrm{Y}$ & $\mathrm{Y}$ & $\mathrm{Y}$ & $\mathrm{Y}$ & $\mathrm{Y}$ & $\mathrm{Y}$ & $\mathrm{Y}$ & $\mathrm{Y}$ & $\mathrm{Y}$ & $\mathrm{Y}$ & $\mathrm{Y}$ & $\mathrm{Y}$ \\
\hline & NOR1 & $\mathrm{Y}$ & $\mathrm{Y}$ & $\mathrm{Y}$ & $\mathrm{Y}$ & $\mathrm{Y}$ & $\mathrm{Y}$ & $\mathrm{Y}$ & $\mathrm{Y}$ & $\mathrm{Y}$ & $\mathrm{Y}$ & $\mathrm{Y}$ & $\mathrm{Y}$ \\
\hline & AUS3 & $\mathrm{N}$ & $\mathrm{Y}$ & $\mathrm{Y}$ & $\mathrm{Y}$ & $\mathrm{Y}$ & $\mathrm{Y}$ & $\mathrm{Y}$ & $\mathrm{Y}$ & $\mathrm{Y}$ & $\mathrm{Y}$ & $\mathrm{Y}$ & $\mathrm{Y}$ \\
\hline \multirow{4}{*}{ Fig.2 } & AUS1 & $\mathrm{N}$ & $\mathrm{N}$ & $\mathrm{N}$ & $\mathrm{N}$ & $\mathrm{Y}$ & $Y$ & $\mathrm{Y}$ & $\mathrm{N}$ & $Y$ & $\mathrm{Y}$ & $\mathrm{Y}$ & $\mathrm{Y}$ \\
\hline & UK1 & $\mathrm{N}$ & $\mathrm{N}$ & $\mathrm{N}$ & $\mathrm{N}$ & $\mathrm{N}$ & $\mathrm{N}$ & $\mathrm{N}$ & $\mathrm{N}$ & $\mathrm{Y}$ & $\mathrm{Y}$ & $\mathrm{Y}$ & $\mathrm{Y}$ \\
\hline & UK3 & $\mathrm{N}$ & $\mathrm{N}$ & $\mathrm{N}$ & $\mathrm{N}$ & $\mathrm{N}$ & $\mathrm{N}$ & $\mathrm{N}$ & $\mathrm{N}$ & $\mathrm{Y}$ & $\mathrm{Y}$ & $\mathrm{Y}$ & $\mathrm{Y}$ \\
\hline & UK4 & $\mathrm{N}$ & $\mathrm{N}$ & $\mathrm{N}$ & $\mathrm{N}$ & $\mathrm{N}$ & $\mathrm{N}$ & $\mathrm{N}$ & $\mathrm{N}$ & $\mathrm{Y}$ & Y & $\mathrm{N}$ & $\mathrm{N}$ \\
\hline \multirow{2}{*}{ Fig.3 } & FR1 & $\mathrm{N}$ & $\mathrm{N}$ & $\mathrm{N}$ & $\mathrm{N}$ & $\mathrm{N}$ & $\mathrm{N}$ & $\mathrm{N}$ & $\mathrm{N}$ & $\mathrm{N}$ & $\mathrm{N}$ & $\mathrm{Y}$ & $\mathrm{Y}$ \\
\hline & AUS2 & $\mathrm{N}$ & $\mathrm{Y}$ & $\mathrm{Y}$ & $\mathrm{N}$ & $\mathrm{Y}$ & $\mathrm{Y}$ & $\mathrm{Y}$ & $\mathrm{Y}$ & $\mathrm{N}$ & $\mathrm{N}$ & $\mathrm{N}$ & $\mathrm{N}$ \\
\hline \multirow{2}{*}{ Fig. 4} & GER1 & $\mathrm{N}$ & $\mathrm{Y}$ & $Y$ & $\mathrm{Y}$ & $\mathrm{Y}$ & $\mathrm{Y}$ & $\mathrm{Y}$ & $\mathrm{Y}$ & $\mathrm{Y}$ & $\mathrm{Y}$ & $\mathrm{Y}$ & $\mathrm{Y}$ \\
\hline & GER2 & $\mathrm{N}$ & $\mathrm{Y}$ & $\mathrm{Y}$ & $\mathrm{Y}$ & $\mathrm{Y}$ & $\mathrm{Y}$ & $\mathrm{Y}$ & $\mathrm{Y}$ & $\mathrm{Y}$ & $\mathrm{Y}$ & $\mathrm{Y}$ & $\mathrm{Y}$ \\
\hline
\end{tabular}

Table 3 - Knowledge Transfer Channels vs. knowledge transfer office architectures.

\subsection{Conclusions and Practical Implications}

In recent years, considerable attention by researchers and policy makers has been focused on improving the knowledge flows between universities and industry, to help create the innovations required to face some of the major challenges facing society today. This research contributes to the growing debate on the strategic challenges of universityindustry knowledge transfer and offers an insight into how to manage this activity of strategically aligning multiple stakeholder goals through exploring different structural 
arrangements of KTOs, how they correspond to types of knowledge transfer channels offered and the benefits and challenges each arrangement brings.

This research provides preliminary insights from 12 KTOs. What it is not possible to conclude is a single most beneficial architecture for KTOs. This is due to a wide range of constraints and external factors, such as access to start-up funding, type of knowledge being transferred or of a number of enablers such as regional policy and regional systems of innovation or even for stakeholder strategic objectives such as the desire for income creation within host institutions, amongst many other things. Thus it is suggested there is no 'one size fits all' model. Whilst there is a recent trend, particularly in the UK, where universities are beginning to outsource their KTO activities, this research identifies that different KTO architectures presents varying benefits and challenges and it is important to align the architecture to the type of knowledge transfer activities the university wishes to be involved in. The findings of this research will help knowledge transfer staff and university managers visualise and align strategic priorities and challenges of universityindustry knowledge transfer and then consider what architecture to adopt accordingly, perhaps utilising a blend of arms-length and internal structures to focus on the strategic targets for the institutions or for their respective regions or economies.

There are a number of limitations within this research which need to be identified. First, the date presented is limited and utilised a self-selection sampling technique therefore does not lend itself to generalisation. In addition, the findings are presented on a snap-shot survey. Future research should adopt a longtitudinal study to allow exploration of the constraints and external factors listed above and provide a more temporal dimension to knowledge transfer architecture. For example perhaps an internal KTO is a starting point and with success, a degree of autonomy is offered, culminating in a separate organisation structure. Equally, instead of a degree of success presenting autonomy, perhaps a degree of failure leads to the extension of autonomy. This research was exploratory however, provides a good foundation to extend this study to explore these respective architectures further to see if there are any additional variants in operation and then identify what models are the most prevalent across different sectors, across different regions or perhaps across different institutional cultures.

AGRAWAL, A., K 2001. University to Industry Knowledge Transfer: Literature review and unanswered questions. International Journal of Management Reviews, 3, 285-302.

ALEXANDER, A., T \& CHILDE, S., J. A Framework for Knowledge Transfer. Advances in Production Management Systems, 2011 Stavanger, Norway. Springer.

ALEXANDER, A., T \& CHILDE, S., J 2012a. Innovation: A Knowledge Transfer Perspective. Production Planning \& Control, Special Edition on Collaborative Innovation

ALEXANDER, A., T, PEARSON, S., R, FIELDING, S., N \& BESSANT, J., R 2012. The Open Innovation Era - Are University Services up to the Challenge? In: BITRAN, I. \& CONN, S. (eds.) The XXIII ISPIM Conference - Action for Innovation: Innovating from Experience Barcelona, Spain: Wiley \& Sons.

ALEXANDER, A. T. \& CHILDE, S. J. 2012b. A framework for the transfer of knowledge between universities and industry. In: FRICK, J. (ed.) Advances in Information \& Comunication Technology. New York: Springer. 
BOZEMAN, B., FAY, D. \& SLADE, C. 2013. Research collaboration in universities and academic entrepreneurship: the-state-of-the-art. . The Journal of Technology Transfer, 38, 1-67.

BRUNEEL, J., D’ESTE, P. \& SALTER, A. 2010. Investigating the factors that diminish the barriers to university-industry collaboration. Research Policy, 39, 858-868.

CARAYANNIS, E. \& CAMPBELL, D. J. 2011. Open Innovation Diplomacy and a 21st Century Fractal Research, Education and Innovation (FREIE) Ecosystem: Building on the Quadruple and Quintuple Helix Innovation Concepts and the “Mode 3” Knowledge Production System. Journal of the Knowledge Economy, 2, 327-372.

EPPLER, M. J. \& MENGIS, J. 2004. The concept of information overload: A review of literature from organization science, accounting, marketing, MIS, and related disciplines. Information Society, 20, 325-344.

GUERRERO, M., CUNNINGHAM, J. A. \& URBANO, D. 2015. Economic impact of entrepreneurial universities' activities: An exploratory study of the United Kingdom. Research Policy, 44, 748-764.

HALFORD, G. S., WILSON, W. H. \& PHILIPS, S. 1998. Processing capacity defined by relational complexity: Implications for comparative, developmental, and cognitive psychology. Behavioural and Brain Sciences, 21, 831-64.

HOWELLS, J. 2006. Intermediation and the role of intermediation in innovation. Research Policy, 35, 715-728.

LEE, Y. S. 1998. University-Industry Collaboration on Technology Transfer: Views from the Ivory Tower. Policy Studies Journal, 26, 69-84.

MCADAM, M., MILLER, K. \& MCADAM, R. 2016. Situated Regional University Incubation: A Multi-level Stakeholder Perspective. Technovation, Forthcoming.

MCADAM, R., MILLER, K., MCADAM, M. \& TEAGUE, S. 2012. The development of University Technology Transfer stakeholder relationships at a regional level: Lessons for the future. Technovation, 32, 57-67.

MILLER, K., MCADAM, M. \& MCADAM, R. 2014. The changing university business model: a stakeholder perspective. $R$ and D Management, 44, 265-287.

MOWERY, D., NELSON, R., SAMPAT, B. \& ZIEDONIS, A. 2015. Ivory tower and industrial innovation: University-industry technology transfer before and after the Bayh-Dole Act, Stanford University Press.

O’SHEA, R., CHUGH, H. \& ALLEN, T. 2008. Determinants and consequences of university spinoff activity: a conceptual framework. The Journal of Technology Transfer, 33, 653-666.

PACEC 2009. Evaluation of the Effectiveness and Role of HEFCE Third Stream Funding. Cambridge: PACEC - Public \& Corporate Economic Consultants.

PACEC 2012. Strengthening the contribution of English Higher Education Institutions to the Innovation System: Knowledge Exchange and HEIF Funding. In: HEFCE (ed.). Cambridge: PACEC.

PACHE, A.-C. \& SANTOS, F. 2010. When worlds collide: The internal dynamics of organizational responses to conflicting institutional demands. Academy of Management Review, 35, 455-476.

PERKMANN, M. \& SCHILDT, H. 2015. Open data partnerships between firms and universities: The role of boundary organizations. Research Policy, 44, 1133-1143.

PRIGGE, G., W 2005. University - industry partnerships: What do they mean to Universities. Industry \& Higher Education, 19, 221 - 229. 
SHARIFI, H. \& LIU, W. 2010. An Exploratory Study of Management of University Knowledge Transfer Offices in the UK. In: RESEARCH, A. I. O. M. (ed.) Academic Publications. London: Management School, University of Liverpool.

SIEGEL, D. S., WALDMAN, D. \& LINK, A. 2003. Assessing the impact of organizational practices on the relative productivity of university technology transfer offices: an exploratory study. Research policy, 32, 27-48.

SMALLBONE, D., KITCHING, JOHN, BLACKBURN, ROBERT, AND MOSAVI, SARA 2015. Anchor institutions and small firms in the UK: A review of literature on anchor institutions and their role in developing management and leadership skills in small firms. UK Commission for Employment and Skills. 